\title{
Local History Materials in One College Library
}

Miss Meyer is librarian, Russell Sage College.

A cogent plea for the signifiance of $A$ local history materials for the small college library came a few years ago from the librarian of Beloit College. ${ }^{1} \mathrm{Mr}$. Paine ${ }^{2}$ underscored the library's obligation, as a department in a tax-fee institution, to join with certain existing neighboring agencies as the public library and historical society in acquiring, preserving and making accessible records of local history. A program planned to avoid overlapping effort among the cooperating institutions was recommended as highly advisable. Possible rewards were suggested in a widening community interest in the college library, and in enriched instruction through the use of original sources for students' independent investigations.

At Russell Sage College Library, Troy, N.Y., varied factors have contributed to the possession of a small, not infrequently used collection of books, newspapers, manuscripts, scrapbooks and other items pertaining to the history of Troy and its outlying districts. A vivid and colorful industrial past has truly existed in this city, which has been continuously casting church bells since $\mathrm{I} 808$. It is said to have made the first tower clocks, surveying instruments and detachable collars produced in this country, and its foundries in 186I supplied armor bars and

${ }^{1}$ Paine, Clarence S. "Materials of State and Local History in College Libraries." College and Research Libraries, 7:41-4, January 1946.

$2 \mathrm{Mr}$. Paine, formerly librarian of Beloit (Wis.) College, is now librarian of the Carnegie Library, Oklahoma City. rivets for the sensational ironclad "Monitor." In the Civil War period, Titus Eddy, and later his son James, made indelible ink out of soot drawn from burning resin and beef bones, using a secret formula of the father's invention. The currency and stamps used by the United States Government were, for more than 40 years, printed with this special ink made after the weekly burning in the small brick furnace on the family estate overlooking the Hudson.

Prosperous business areas quickly developed intellectual and social interests. Emma Willard, pioneer educator, in 1817 established her widely esteemed Troy Female Seminary on the grounds now occupied by Russell Sage College. Years later Madame Willard, writing of her town, said: "And although in my travels I have 'for several virtues liked several' places, yet I have seen none for which I would wish to exchange Troy, as a place of residence." As early as 1838 the Troy Academy of Music was founded, so reads an early announcement, "to act as a musical agent for the people." Handsome theaters and opera houses attracted famous theatrical and musical stars, and many productions, later to be New York successes, were launched as up-state try-out performances on their stages.

Since 1891 only one lengthy history of Troy has been written. In the intervening time the town has passed the peak of

${ }^{3}$ Goddard, Abba H. The Trojan Sketch Book. Troy, N.Y.. Young and Hartt, 1846, p. 162. 
its prosperity, families identified with its industries have scattered, and in consequence, their homes have been dismantled. Inevitably a wealth of historical evidence has come to light, much of which rightly should remain in the town and county. The local historical society, lacking an official staff, and until very recently without prospect of headquarters, has long been forced to depend upon the public library to house its acquisitions. However, a hardpressed public library, while recognizing and assuming such an obligation, cannot perform a dual function of this type without adequate personnel. An inescapable result has been the inclusion of the college library in a somewhat undefined cooperative attempt to preserve community historical records.

The scheme has been reinforced substantially by a thriving Friends of the Russell Sage Library, whose members, recognizing the college as a possible repository, have opportunely rescued valuable books, papers and memorabilia from destruction and sent them to its library. A few of the group have become zealous scouts in hunting out unrecognized treasures abandoned to attic oblivion.

The various gifts received, and the uses to which they have been put, are evidence that Mr. Paine's point is well taken. Russell Sage College Library now houses, among other valuable possessions, files belonging to a lumber company which operated between 1888 and 1927 ; a manuscript history of the second oldest drug house in the country, established in 1787 ; and three cartons contain the papers of a firm nationally famous for its furnaces, stoves and heaters. Heirs of the inventor of the secret ink formula have contributed a fascinating collection of advertising materials, orders and elaborate bill heads used in the family business. Emma Willard is represented by some 30 letters and papers inaccessible to research workers until the college acquired them. There are old deeds for real estate and other indentures. A local newspaper gives a realistic account of John Brown's last hours and execution. Publishing is reflected in magazines, almanacs and "sketch books" carrying Troy imprints, a sample being the Columbian Orator: Containing. . Pieces Together with Rules Calculated to Improve Youth. . . in the Ornamental and Useful Art of Eloquence. Playbills and vocal society concert programs testify to musical tastes.

It should be parenthetically stated that some of the gifts have not been outright donations. They have been in the nature of deposits which will be turned over to the historical society when they can be cared for adequately. But the mere temporary possession of such documents has obvious benefits to a college library of slightly over 50,000 volumes. Its book stock, although in a healthy state of constant growth, is not particularly strong in source items which best supply the needs of students working on individual investigations.

It has been successive groups of senior history majors who, working under careful guidance in their seminars, have made intelligent and practical use of the materials at hand. Seminar papers required for graduation have, in a number of cases, been based primarily on historical documents owned by the college library. The results now stand on the library shelves and are often consulted, not only by students of the college, but by townspeople sensitive to the rich historical background of their city. Phases of political, economic and social history in Troy, hitherto unexplored in any detail, have been investigated. A study of traveling theatrical companies playing the town between 1892 and 1895 , together with their productions, has been titled The State, an Echo of the Public Voice. Edward Murphy, Jr., United States senator and 
vigorous boss of the local Democratic machine for over twenty years, is the subject of one paper, and General John Ellis Wool, vivid soldier of Mexican and Civil War fame, the hero of another. Industrial Troy between 1850 and the Panic of 1873 is represented by a study of its once flourishing industries- the bell foundries, iron works, collar, cuff and shirt factories, stove works and surveying instrument plants. Troy newspapers have been analyzed and evaluated through their handling of Mexican War news. It is no enthusiastic overstatement of fact to say that a number of these studies would pass as adequate masters' theses, and that their contents will be highly useful to any future historian of Troy.

A glance back at the paragraphs describing the assortment of treasures already acquired by the college library, will show that many of them are still to be studied. Past and present conditions point to complete justification of the library's participation in any attempt to save and make available certain historical records. It is undeniably true, as Mr. Paine predicted, that an enriched teaching of history has stimulated a student interest in the community which might not have risen otherwise. Friends of the college, with a feeling of confidence that gifts of historical papers will be used to advantage, have been encouraged to increase their contributions. In one case at least, a friend of the library has become a benefactor of the college in a most gratifying and substantial form. A new history of Troy is yet to be written. In Russell Sage College Library original sources await some future historian.

\section{American Theological Library Association Holds Third Annual Conference}

Approximately 50 theological librarians gathered on the campus of Chicago Theological Seminary June 20 and 21 for a constructive conference centering upon specific library problems as they are met in the libraries of our Protestant theological seminaries.

Major topics of the conference were the following: Micro-Photography in Essential Library Materials; Exchange of Duplicate Religious Periodicals; Denominational Bibliography; Religious Periodical Indexing; A Master List of Research Studies in Religion; Library Buildings and Equipment; Recruitment and Training of Library Personnel; The Library and the Seminary Curriculum; and Library Extension Services.

The program was made up of papers by specialists both within and beyond the profession. There were also presented reports by project committees which have been at work over the past year. A number of new project committees will be at work for the year ahead.

Officers elected for 1949-50 are: President, Jannette Newhall, librarian, Boston University School of Theology; vice president, Kenneth S. Gapp, librarian, Princeton Theological Seminary; secretary, Robert F. Beach, librarian, Garrett Biblical Institute, Evanston, Ill.; and treasurer, E. F. George, librarian, Evangelical Theological Seminary, Naperville.

Detailed proceedings of the conference have been published and are being widely distributed. Copies are available upon request to the secretary above. Inquiries concerning the nature and work of the program may be directed to the secretary as well. 